\title{
EDITORIAIS
}

\section{PATOLOGIA SINUSOIDAL DO FÍGADO E ESQUISTOSSOMOSE}

Há muitos anos atrás Eppinger ${ }^{8}$ notou em certos figados em necrópsia a presença de um edema que afastava a parede das sinusóides dos hepatócitos, ampliando o espaço de Disse. Construiu a partir dai a sua "patologia da permeabilidade", julgando que alguns agentes lesivos ao atuar sobre a parede dos sinusóides, aumentava a sua permeabilidade. $O$ edema que dai surgia afastava os hepatócitos da sua fonte de nutrientes, dificultando a difusão dos mesmos. Logo mais se viu que o edema no espaço de Disse era um artefato que surgia no periodo agônico em certos casos e, mais regularmente, como uma alteração postmortem ${ }^{12}$.

Nos tempos modernos entretanto está renascendo a idéia de que uma interferência no transporte de nutrientes dos sinusóides até os hepatócitos è um fenômeno que pode ter fundamental importância na patologia geral do fígado. Não mais devido simplesmente a um edema por defeitos na permeabilidade. Mas, devido a um intrincado mecanismo que pode afetar o delicado micro-ambiente do intersticio hepático.

A circulação mesentério-porta é responsável pelo aporte dos nutrientes absorvidos ao nivel intestinal para o interior do fígado. Ai o sangue passa no interior de capilares especiais, sem membrana basal, dotados de alta permeabilidade e flanqueados pelas traves hepáticas. Os sinusóides são formados por células endoteliais que deixam entre si espaços por onde o plasma pode passar livremente. Contém também as células fagociticas de Kupffer, que são macrófagos especiais, que tem outras importantes funçōes, como seja um efeito modulador sobre a formação de fibrose ${ }^{13}$. Entre os sinusoides e as traves hepaticas está o espaço de Disse, um espaço virtual que contem algumas tibras colágenas isoladas (reticulina), fibroblastos e células armazenadoras de gordura, as células de Ito, bem como certa quantidade de proteoglicanos e proteinas que se associam ao colágeno, como a fibronectina.

Os hepatócitos, no lado que margeiam os sinusóides, exibem microvilosidades que muito ampliam a sua superfície de contacto com o conteúdo presente nos espaços de Disse.

Toda esta delicada estrutura pode ser alterada nas doenças crónicas do figado com o surgimento de membrana basal nos sinusóides (capilarização dos

Recebido para publicação em 1/4/1986

\section{LIVER SINUSOIDAL PATHOLOGY AND SCHISTOSOMIASIS}

Many years ago Eppinger 8 noted in some liver autopsy specimens the presence of oedema which separated the sinusoidal wall from the hepatocyte enlarging the space of Disse. He constructed a concept of permeability pathology related to certain conditions that affected the sinusoidal wall and increased permeability. The resultant oedema separated the hepatocytes from their source of nutrients creating difficulties in diffusion. However within a short space of time one saw that this oedema of the space of Disse was usually a post-mortem artifact 12 .

Recently however this concept has been revived and it is thought today that interference with nutrient transport from the sinusoids to the hepatocytes is an important mechanism in liver pathology. Nor is it seen simply as only oedema due to a permeability defect but as an intricate mechanism which can affect the delicate microenviroment of hepatic interstices.

The mesenteric portal circulation is responsible for furnishing nutrients absorbed by the intestine to the liver. The blood passes by special capillaries. without basement membranes. of high permeability between the columns of hepatic cells. The sinusoids are formed of endothelial cells which allow space for free plasma circulation. They also contain the phagocytic cells of Kupffer, specialised macrophages which among other important functions have a regulatory effect as regards formation of fibrous tissue ${ }^{13}$. Between the sinusoids and the hepatic cords is the space of Disse, a hidden space which contains isolated collagen fibres (reticulin), fibroblasts and cells capable of storing fat, the cells of Ito. as well as a certain quantity of proteoglycans and proteins associated with collagen such as fibronectin. The hepatocytes at the sinusoid margins have ample microvilli on their surface which are in contact with the contents of the space of Disse.

All this delicate anatomy can be altered in chronic disease of the liver with the appearance of basement membrane in the sinusoids (capillarization of the sinusoids ${ }^{14}$ ). increase in the fibres or hyperfibres of collagen in the space of Disse and flattening of the villous process at the vascular pole of the hepatocytes ${ }^{10}$. The result is interference with nutrient 
sinusóides ${ }^{914}$ ), aumento das fibras ou hiperfibras do colágeno no espaço de Disse ${ }^{11}$ e achatamento das vilosidades do pólo vascular dos hepatócitos ${ }^{10}$. A consequêencia é uma interferência com o aporte dos nutrientes ao hepatócito e profundas repercussões para a fisiopatologia hepática.

Alguns autores têm apresentado evidências de que são estas alteraçōes intersticiais hepáticas, junto com a consequiente tumefação ou hipertrofia dos hepatócitos, que se correlacionam com os graus de insuficiência hepática, com a hipertensão porta e com o prognóstico da hepatopatia 6101115 . Neste particular convêm lembrar que aproximadamente $10 \mathrm{a}$ $15 \%$ dos alcoólatras com cirrose hepática comprovada não exibem alterações clínicas ou laboratoriais ${ }^{6}$, o que mostra que outros fatores que não a cirrose per se são funcionalmente mais importantes.

Dentro desta ordem de idéias seria importante assinalar a contribuição que os estudos sobre a patologia da forma hépato-esplènica da esquistossomose já vêm trazendo ao assunto, os quais ainda são relativamente pouco conhecidos no Brasil e no exterior.

Há já um certo tempo que foi chamada a atenção para o fato de que a esquistossomose hépato-esplênica descompensada não representava uma progressão para o quadro de cirrose ${ }^{37}$. Não foi encontrada correlação entre o grau de insuficiência hepática e a regeneração nodular do parênquima, mas sim com a presença de hepatite crônica e fibrose intersticial 5 . Um indicador de gravidade das lesões foi o grau da pressão sinusoidal (pressão da veia hepática ocluida) ${ }^{5}$, que por sua vez foi demonstrada ser dependente do fluxo arterial aumentado ${ }^{2}$. Nos casos com maior elevação da pressão sinusoidal, além da fibrose intersticial, aparecia proeminente a trama reticular hepática.

Assim, a esquistossomose hepática avançada, primariamente dependente de uma obstrução porta intra-hepática, que dá origem à hipertensão porta, desenvolve uma hipertrofia compensadora da artéria hepática ${ }^{4}$ que aumenta a pressão nos sinusoides e causa alterações no sistema intersticial, as quais parecem se correlacionar com o grau de compromentimento da função hepática.

Este conceito foi testado experimentalmente em ratos nos quais se praticou a ligadura da veia porta ${ }^{1}$. Após períodos de tempo variáveis, os animais exibiam hipertrofia arterial, capilarização dos sinusóides e a presença de hiperfibras colágenas nos espaços de Disse.

Os estudos com a esquistossomose indicam: a) a importância fisiopatológica das alterações intersticiais hepáticas; $b$ ) uma etio-patogenia para tais alteraçōes, as quais seriam decorrentes da arterialização hepática, criando condições para a capilarização dos sinusóides e o depósito de colágeno nos espaços de Disse, o que está de acordo com a lei de Thoma que diz delivery to the hepatocytes resulting in profound changes in liver physiopathology.

Some authors report evidence that it is these interstitial hepatic alterations together with swelling and hypertrophy of the hepatocytes which can be correlated with the degree of hepatic insufficiency, portal hypertension and prognosis of the hepatic pathology 6101115 . In this regard it is stated that approximately $10-15 \%$ of alcoholics with hepatic cirrhosis do not have clinical or laboratory abnormalities ${ }^{6}$ showing that factors other than cirrhosis are functionally more important.

Among these rationalizations it is important to remember the contribution of studies on the pathology of the hepatosplenic form of schistosomiasis to this subject. Studies which are relatively little known in Brazil or abroad.

For some time attention has be drawn to the fact that decompensated hepatosplenic schistosomiasis does not progress to cirrhosis ${ }^{3}$. There is no correlation between the degree of hepatic insufficiency and nodular regeneration of the parenchyma. However there is such a correlation with chronic hepatitis and interstitial fibrosis 57 . An indication of the severity of these lesions is the degree of sinusoidal pressure (hepatic wedge pressure) ${ }^{5}$ which has been shown to be independent of the increased arterial flow ${ }^{2}$. In cases with high sinusoidal pressure and interstitial fibrosis reticular hepatic network is prominent.

Thus hepatic schistosomiasis depends primarily on intra hepatic portal obstruction which gives rise to portal hypertension and induces a compensatory hypertrophy of the hepatic artery, with increased sinusoidal pressure resulting in alterations in the interstitial system which correlates with the degree of hepatic dysfunction. This concept was tested experimentally in rats in which the portal vein was ligated ${ }^{\prime}$ After variable periods the animals showed arterial hypertropy, capillarization of the sinusoids and presence of hyperfibres of collagen in the spaces of Disse.

These studies with schistosomiasis show: a) the physiopathological importance of alterations in the hepatic interstitium; b) an aetiology for this pathological changes which depends on hepatic arterialization creating conditions for capillarization of the sinusoids and deposition of collagen in the spaces of Disse. This is in agreement with Thoma's law which states that the 
estar a estrutura de um vaso sangüineo relacionado com a pressão no seu interior.

\section{REFERÊNCIAS BIBLIOGRÁFICAS}

\section{Almeida-Melo CR, Grimaud JA, Andrade ZA. Changes} in the rat liver induced by total portal vein ligation. Brazilian Journal of Medical and Biological Research 16:49-53, 1983.

2. Alves CAP, Alves AR, Abreu WN, Andrade ZA. Hepatic artery hypertrophy and sinusoidal hypertension in advanced schistosomiasis. Gastroenterology 72:126-128, 1977.

3. Andrade ZA. Can schistosomiasis cause hepatic cirrhosis? Gazeta Médica da Bahia 68:34-41, 1968.

4. Andrade ZA, Cheever AS. Alterations of the intrahepatic vasculature in hepatosplenic schistosomiasis mansoni. American Journal of Tropical Medicine and Hygiene 20:425-432, 1971.

5. Andrade ZA, Ferraz GS. A hepatopatia esquistossomótica. Arquivos de Gastroenterologia 8:131-136, 1971

6. Bruguera M, Bordas JM, Rodés J. Asymptomatic liver disease in alcoholics. Archives of Pathology and Laboratory Medicine 101:644-647, 1977.

7. Cheever AW, Andrade ZA. Comparison of pathological changes in the liver of subjects with compensated and decompensated hepatosplenic schistosomiasis mansoni. Gazeta Médica da Bahia 70:67-74, 1970. structure of a blood vessel is related to the pressure in its lumen.

8. Eppinger H. Patologia de la permeabilidade. Editorial Labor S.A., Barcelona, 1952.

9. Grimaud JA, Borojevic R. Chronic human schistosomiasis mansoni: pathology of the Disse's space. Laboratory Investigation 36:268-173, 1977.

10. Orrego H. Determinantes morfológicos de la gravedad clinica de la cirrhosis hepática. Simpósio Hispanoparlante de Hepatologia 2:174-183, 1985.

11. Orrego H, Blendis LMM, Crossley IR, Medline A, MacDonald A, Ritchie A, Israel Y. Correlation of intrahepatic pressure with collagen in the Disse space and hepatomiegaly in humans and in the rat. Gastroenterology 80:545-556, 1981.

12. Popper H. Signiticance of agonal changes in the human liver. Archives of Pathology 46:132-144, 1948.

13. Rojkin M, Pérez-Tamayo, R. Liver fibrosis. In Hall DA, Jackson DS (eds) Intemational Review of Connective Tissue Research 10:333-394, 1983.

14. Schaffner F, Popper H. Capillarization of hepatic sinusoids in man. Gastroenterology 44:239-242, 1963.

15. Vidins EL, Britton RS, Medline A, Blendis LM, Israel Y, Orrego $\mathrm{H}$. Sinusoidal caliber in alcoholic and nonalcoholic liver disease. Diagnostic and pathogenic implications. Hepatology 5:408-414, 1985.

Zilton A. Andrade

Centro de Pesquisas Gonçalo Moniz, Universidade Federal da Bahia

Rua Valdemar Falcão, 121, Brotas 40000 - Salvador - Bahia 